\title{
Pre-collisional geodynamics of the Mediterranean Sea: the Mediterranean Ridge and the Tyrrhenian Sea
}

\author{
Jean Mascle and Eric Chaumillon \\ Géosciences Azur, Laboratoire de Géodynamique Sous-Marine, Villefranche-sur-Mer, France
}

\begin{abstract}
Today the Mediterranean Sea consists of a series of small-sized and almost geographically disconnected oceanic or continental crust rooted marine basins. It is also an area almost totally surrounded by mountain convergence between the two major African and. This overall geodynamic setting results from a long term tion of surrounding the two major, African and European, plates. Previous collisions have led to the edificaback-arc basins and coins, while subduction and new-collisional processes tend to create new extensional back-arc basins and wide tectonized accretionary prisms. In this paper we briefly outline the most recent and Mediterranean Ridge, which masin that has developed in the Mediterranean, i.e., the Tyrrhenian Sea, and the chain.
chean Ridge, which may be regarded as a collisional sedimentary wedge predating a future mountain
\end{abstract}

Key words Mediterranean Sea - collision - backarc - accretionary prism

\section{Introduction}

One of the most conspicuous examples of ongoing continental collision is expressed in the Mediterranean Sea where the long term Africa-Europe convergence has resulted, for the last $30 \mathrm{My}$, in the progressive opening of back-arc type basins (the Western Mediterranean Balearic-Provençal basin, the Tyrrhenian and Aegean Seas) and the construction of major tectonized sedimentary wedges: the External Calabrian Arc (ECA), and the Mediter-

Mailing address: Dr. Jean Mascle, Géosciences Azur, Laboratoire de Géodynamique Sous-Marine, B.P. 48, 06235 Villefranche-sur-Mer, France; e-mail: mascle@ccrv. obs.vlfr.fr ranean Ridge (MR). Both features, extensional basins and accreted wedges, have been interpreted as results of the subduction of the Mesozoic African oceanic lithosphere and of its thick sedimentary cover, beneath the Calabrian and the Aegean arcs. As a consequence of this overall convergence, the Mediterranean Sea is characterized today as an area of intense seismicity and active volcanism, and a marine domain, made of small oceanic spaces of different ages now totally surrounded by continental land masses (fig. 1).

In this paper we briefly review and discuss two domains of the Mediterranean Sea resulting from its very recent evolution: the Mediterranean Ridge, as an example of a large-scale tectonized sedimentary complex which probably started to edificate from the late Miocene and the Tyrrhenian Sea as an example of a land-locked back-arc basin, which initiated also in the late Miocene. 


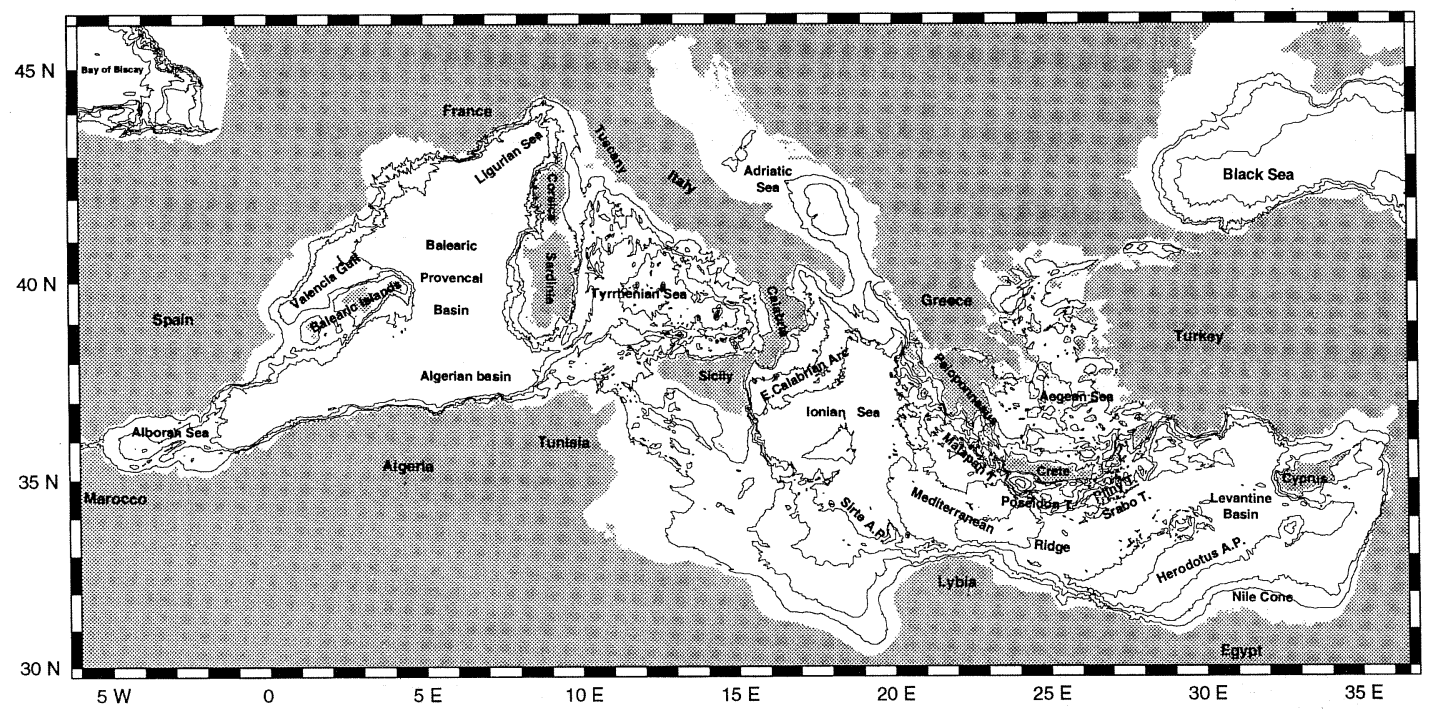

Fig. 1. Main domains of the Mediterranean Sea shown on a simplified bathymetric map (contour interval 200, 1000, 2000, 3000 and $4000 \mathrm{~m}$ ).

\section{The Mediterranean Ridge: an example of a pre-collisional wedge}

\subsection{Geodynamic setting}

In the Eastern Mediterranean (figs. 1 and 2), the Southern Aegean corresponds to an area of strong seismic activity where the hypocenters define a northward dipping seismic slab, currently interpreted as the subducting African lithosphere (Papazachos and Comninakis, 1971). Northward of this slab, tomographic studies indicate the presence, at depth, of a second slab, supposed to be a remnant of a previously subducted portion of the African lithosphere (Spakman et al., 1988). It has been argued that the Hellenic subduction may have initiated some 46 My ago (Spakman et al., 1988). An alternative hypothesis, based on the timing of extensional tectonics within the Aegean region, proposed that the present day subduction only initiated some $13 \mathrm{My}$ ago (Le Pichon and Angelier, 1979).

South of the Hellenic trench system (fig. 2), the shallow seismicity remains quite important, at least beneath the northern edge of the Mediterranean Ridge (MR). Such a seismic activity might indicate the southern prolongation of the Aegean continental margin, south of the Hellenic trenches (Lallemant et al., 1994), as also partly substantiated by seismic and gravity data (Truffert et al., 1993). Further south, the axial and outer MR domains (figs. 2 and 3) consist of thick piles of deformed sediments (up to $10 \mathrm{~km}$ ) (Makris, 1976; Makris and Stobbe, 1984; De Voogd et al., 1992). In those areas, swath bathymetry and sidescan sonar data demonstrate that the MR surface exhibits only very gentle slopes $\left(1^{\circ}\right.$ to $2^{\circ}$ in average) and numerous small amplitude surficial deformations, which have been interpreted as due to concurrent compressive deformation, gravitational gliding and mud volcanism (Belderson et al., 1978; Kenyon et al., 1982; Stride et al., 1977; Le Pichon et al., 1982; Kastens et al., 1992; Foucher et al., 1993; Limonov et al., 1994, 1996). Mud volcanoes and shale diapirs have effectively been discovered and sampled by coring and drilling, mainly along the MR axis (Cita et al., 1981; Camerlenghi et al., 1992; 
Limonov et al., 1994; Robertson et al., 1996); these features contain early Cretaceous to Miocene brecciated shales suggesting that a probable decollement might exist, at depth, probably within early Cretaceous shales (Ryan et al., 1982). Sedimentological and detailed morphological data on the outer MR tend also to indicate that the ridge growth rate has notably increased during, and after, Messinian times (latest Miocene). These data also suggested that deformation observed along the actual MR was consistent with a shallow decolle- ment located near the top of the Messinian salt-rich layers (Kastens, 1991; Kalstens et al., 1992).

The origin and nature of the Hellenic trenches, which bound the MR towards the North (figs. 1 and 2) are still a matter of controversy. Four hypotheses have been proposed:

1) these features are subduction trenches (Rabinowitz and Ryan, 1970);

2) being in forearc setting, the trenches may underline a structural transition between

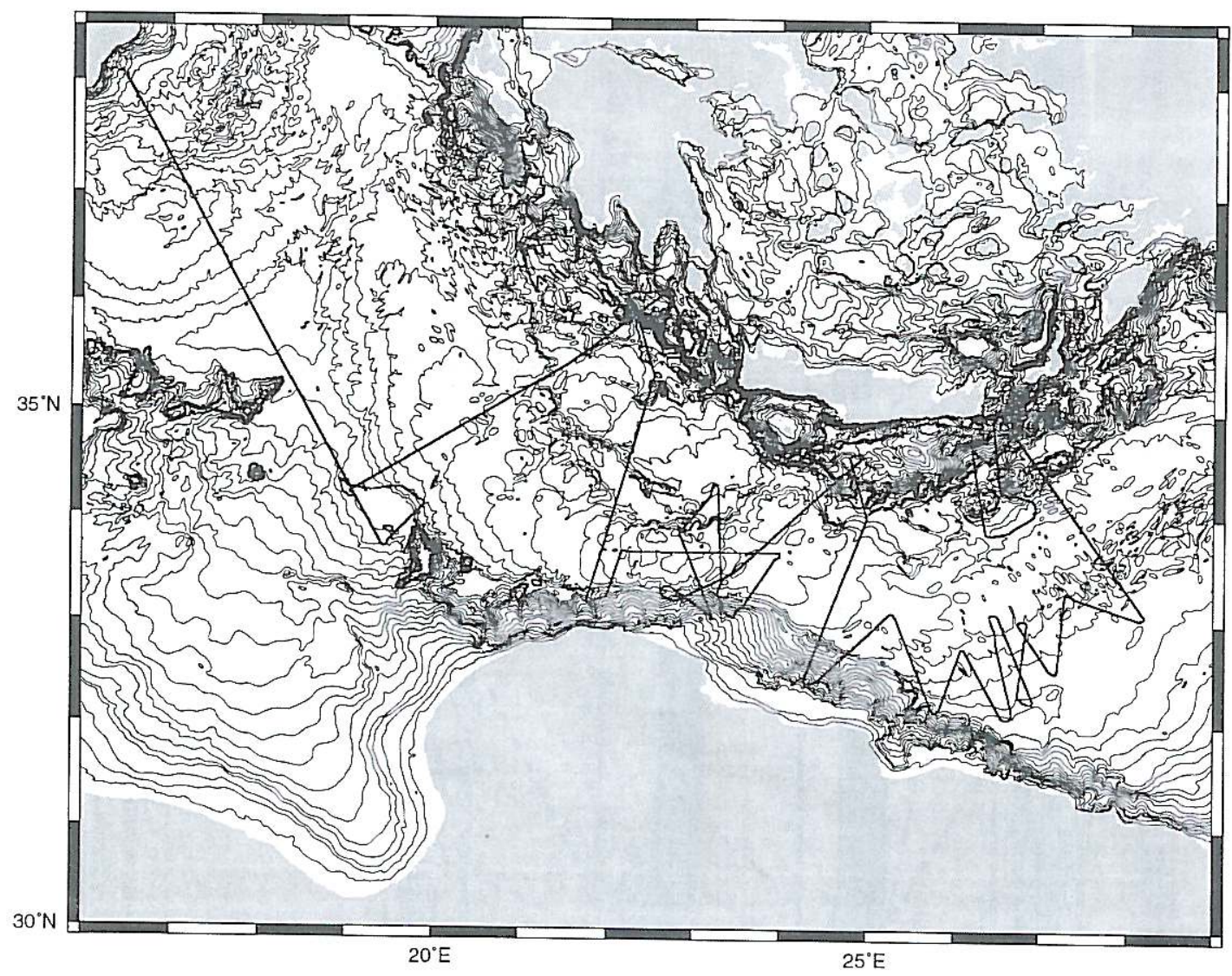

Fig. 2. Detailed bathymetric map of the Central Eastern Mediterranean basin (bathymetric contours $200 \mathrm{~m}$ ) showing most of the Mediterranean Ridge. Towards the north the Aegean continental margin is surrounded by a series of deep (up to $5000 \mathrm{~m}$ ) troughs, forming the Hellenic trench system. Towards the south the Mediterrancan Ridge is almost directly in contact with the Libyan continental margin. Track lines of the PRISMED multichannel seismic survey (1993) are shown (Mascle et al., 1994). 


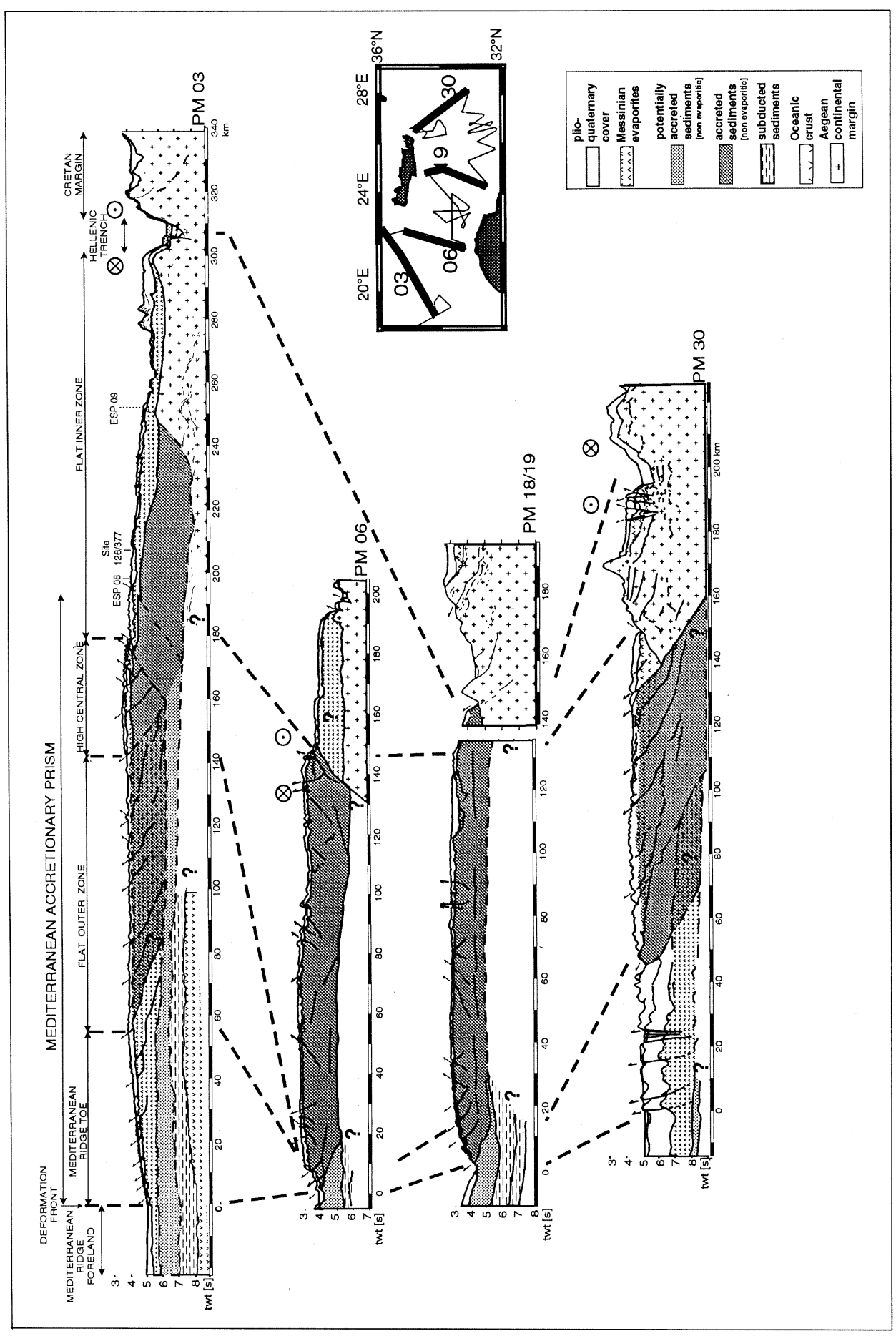

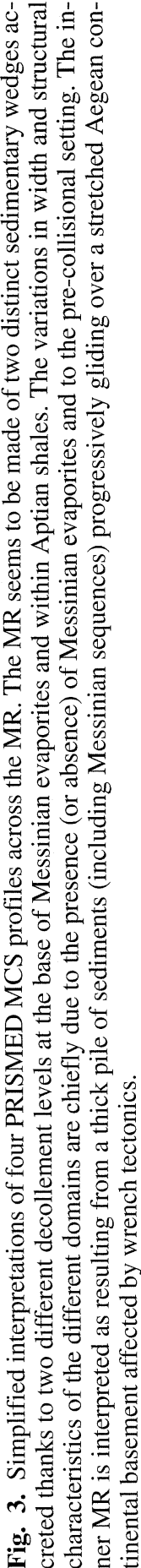


the accreted MR and the stretched Aegean continental crust (Le Pichon et al., 1982);

3 ) the Hellenic trench system consists of a series of extensional basins cut into the Aegean stretched continental crust (Lallemant et al., 1994);

4) since, the kinematics of the MR is apparently ruled by strain partitioning, the Hellenic trenches may be dominated by strike-slip deformations, which accommodate the lateral escape of the inner MR (Le Pichon et al., 1995).

\subsection{Recent data}

Despite several attempts only few useful seismic data are available to better define the MR structural pattern. Multichannel seismic reflection profiles have recently been recorded across the MR, from its outer deformation front to the south, to the Hellenic trenches to the north (fig. 2) (Chaumillon, 1995); these lines allow to characterize several deformational styles in the MR from its contact with the foreland in the south, to the Hellenic trench areas (fig. 3) (Mascle et al., 1994; Chaumillon and Mascle, 1995; Chaumillon et al., 1996).

An important result derived from these new data set concerns the identification of a decollement level beneath both the western (Ionian) and eastern (Levantine) outer MR (fig. 4). The good lateral continuity seen between characteristic reflectors of the lower Messinian evaporites ( $\mathrm{B}$ reflector) and the reflecting sequences imaged at the base of the deformed wedge, is well illustrated by MCS data (Mascle et al., 1994; Chaumillon, 1995). Moreover, the deformational styles, as well as the average very gentle slopes observed over most of the outer MR represent complementary evidence of very low internal and basal frictions within this accreted wedge. Both sets of observations are in good agreement with the mechanical properties of evaporites (Woidt, 1978).

A second significant result from this MCS data set concerns the lateral structural variations of the MR, both on cross-section and along the MR trend (fig. 3). Following Truffert et al. (1993) we distinguish an outer, an axial

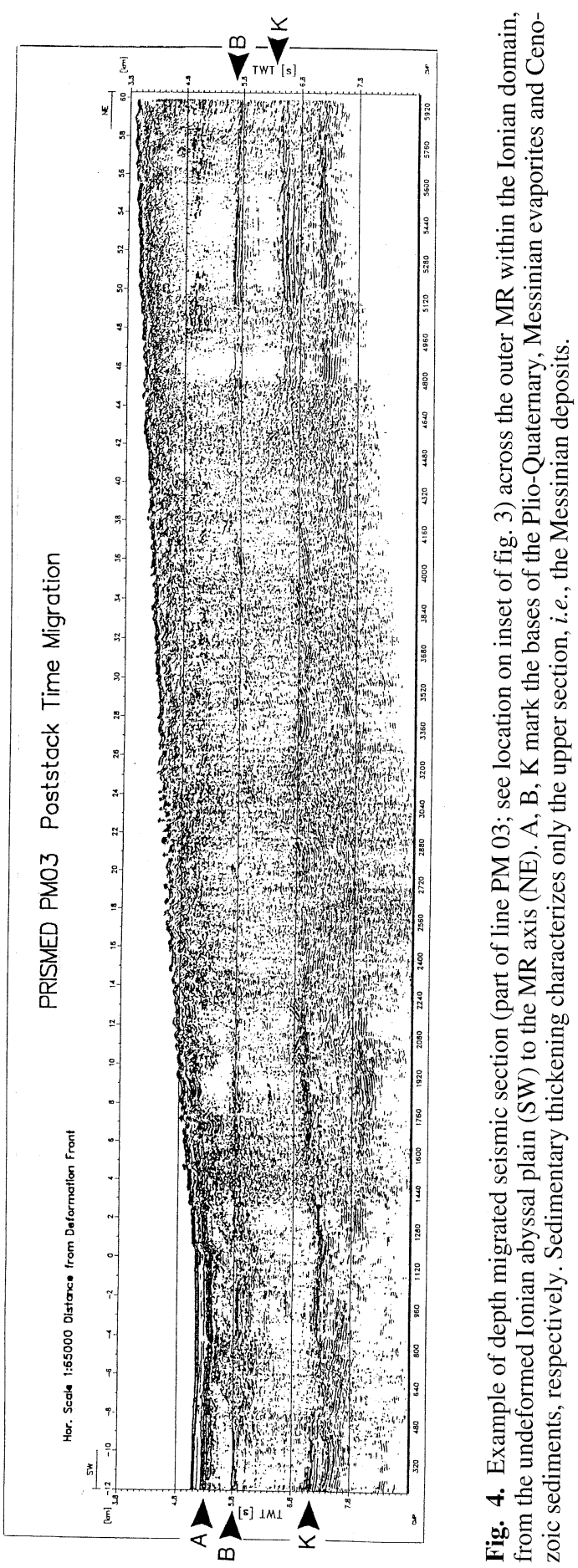


(or crestal) and an inner MR domain. Within the Ionian and Levantine basins, the outer MR consists in a thick sedimentary pile apparently accreted thanks to an evaporitic decollement level (Mascle et al., 1994; Chaumillon et al., 1996).

Towards Libya, the outer MR is characterized by an apparent lack of evaporitic facies, the presence of steeper topographic slopes and of gravity gliding, and the occurrence of imbricated thrust sheets. Such structural heterogeneity is, in our opinion, a direct consequence of lateral changes of Messinian facies and thickness (Chaumillon et al., 1996). Eastward, the outer MR shows a clear increase in fold wavelength and fault spacing; this is clearly correlable with a drastic thickening of the Plio-Quaternary cover, directly linked to the proximity of the Nile cone (Chaumillon and Mascle, 1995).

The transition between the outer and axial MR appears almost everywhere underlined by relatively sharp slope breaks, increases in surficial deformations, the presence of discontinuous reflectors at depth, and by the occurrence of shale diapirs and mud volcanoes (Cita et al., 1981; Ryan et al., 1982; Camerlenghi et al., 1992; Limonov et al., 1996). All together, these peculiarities are considered evidence of an increasing compressive deformation towards North (Chaumillon and Mascle, 1997). A comparable structural pattern characterizes the northern border of the axial MR domain, which appears to be associated with backthrusting. The MR axial domain widens considerably between the Cretan and Libyan margins, where it is characterized by a rather subdued topography (Limonov et al., 1994; Chaumillon and Mascle, 1997).

Within the Ionian basin, the inner MR expresses mainly as a series sedimented and almost undeformed basins characterized, at depth, by high seismic velocities (on the order of $5 \mathrm{~km} / \mathrm{s}$ ), given as indications of a potential continental backstop (Truffert et al., 1993; Lallemant et al., 1994). However, locally we note backthrust deformations and gravitational sliding towards the Hellenic trenches. Finally, south of Crete, the inner MR becomes progressively narrower and may even be only ex- pressed by gentle slopes in direct transition toward the trench domain. In this area the axial MR appears to directly overthrust the Southern Cretan margin. South-east of Crete (between the Strabo and Pliny trenches) (figs. 1 and 2) the Strabo seamounts, which consist of a series of block-faulted and uplifted reliefs, are interpreted as tectonized fragments of the inner MR (Chaumillon and Mascle, 1997).

The northern bordering Hellenic trenches (figs. 1 and 2) may themselves be divided into two types of features:

a) the deep Matapan and Pliny trenches, at the base of the Aegean continental margin, where MCS data and swath bathymetry show indications of strike-slip activities and of deformations of the present day sedimentary infilling (Huchon et al., 1982; Chaumillon and Mascle, 1995);

b) the shallower, Poseidon and Strabo troughs, which rather look like backthrust or nappe fronts indicating an overthrusting of the MR sedimentary pile over the Southern Cretan margin and the Strabo seamounts, respectively (Chaumillon and Mascle, 1997).

\subsection{Interpretation discussion}

Swath bathymetry data as well as sidescan sonar and seismic records allowed us to construct a preliminary structural sketch of the entire MR (fig. 5). This stresses that compression chiefly characterizes the outer and axial MR, while transpression seems to occur mostly at the level of the inner MR and within the Hellenic trench area. Such a structural pattern is in good agreement with a model of strain partitioning as proposed by Le Pichon et al. (1995). The data, however, tend to suggest that partitioning may be chiefly restricted to the Hellenic trenches rather than to parts of the inner MR.

Variable ongoing collision processes between the MR and the Libyan promontory appear to best explain the along-strike MR structural difference. Present-day velocity field models, indicating a minimum velocity within the Central Aegean and lateral accelerations to- 


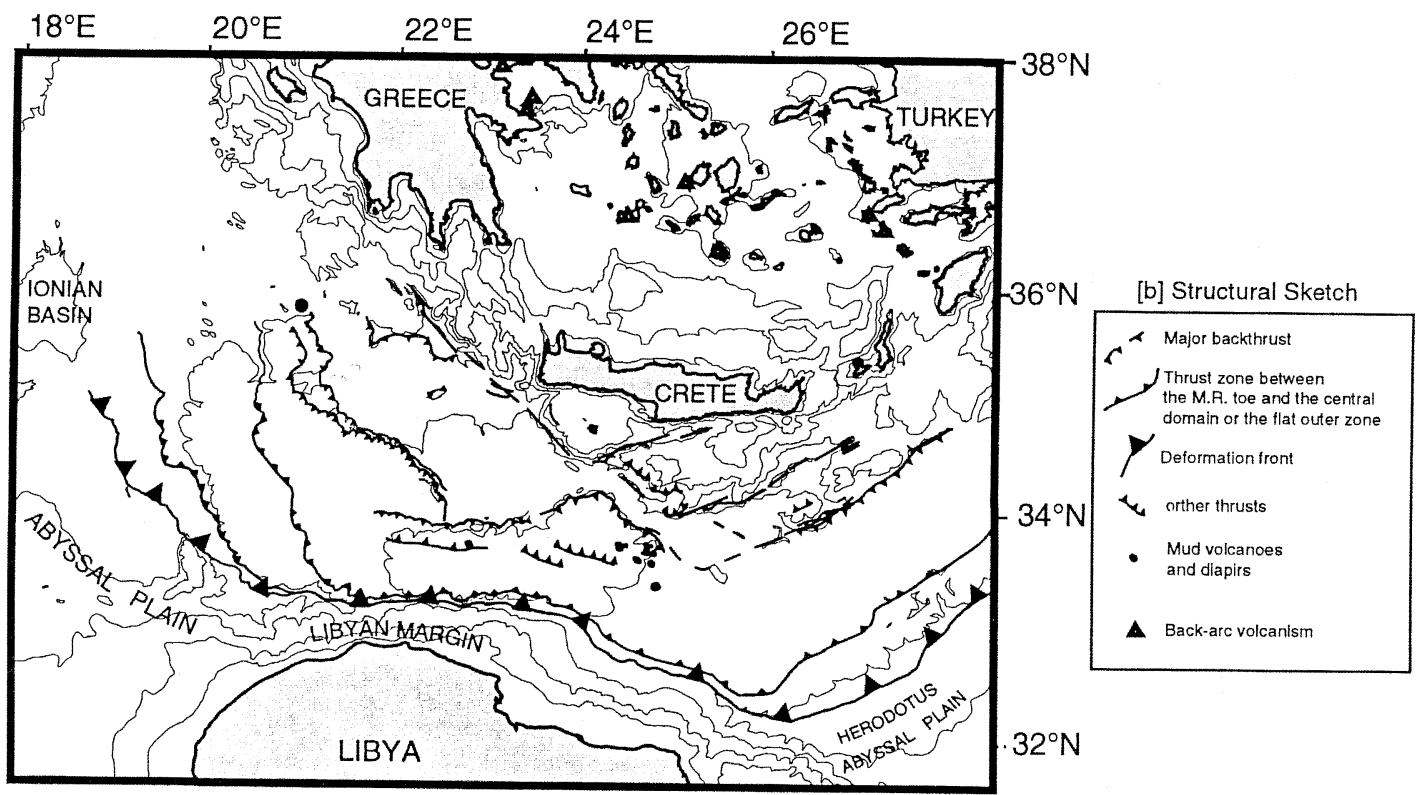

Fig. 5. Tectonic sketch of the MR as deduced from the integration of multichannel seismic data, swath bathymetry and side scan sonar. The MR appears to be made of three distinct structural domains bounded southward by different forelands and northward by the Hellenic trenches. Major backthrusting seems to occur between the central and inner MR domain.

wards the Ionian and Levantine basins with respect to Europe (Le Pichon et al., 1995) are in good agreement with such an overall geodynamic interpretation. However, we believe that incipient-collisional deformation between the central MR and the African margin already initiated during Messinian times, some 6 to $5 \mathrm{My}$ ago. This timing may take into account most of the MR morphostructural characteristics. Today, the high-standing central domain (between Southern Crete and Libya) corresponds to a relatively flat area without clear evidence of thick evaporitic cover; we are thus led to propose that this area was already in a relatively high standing position during Messinian times and separated two deeper basins (the Ionian and Levantine basins) where thick evaporites, now incorporated to the outer MR, were accumulating. The presence of thick, and mechanically weak, sediments would have led to an upward migration of the decollement level from early Cretaceous shales to Messinian evapor- ites, and would have induced a faster outward growth of the MR deformation front.

Such a phenomenon may have initiated a strain partitioning between the main MR sedimentary pile and the Aegean continental margin, as well as subsequent lateral escapes of the Ionian and Levantine outer MR toward southwest and southeast, respectively.

Finally, these hypotheses imply that the present day MR is the combined result of at least two distinct accretionary stages:

a) a pre-Messinian stage, during which an early accreted complex, now located somewhere beneath the axial and inner MR, developed thanks to an early Cretaceous shale decollement;

b) a Messinian to post-Messinian stage, chiefly edificated thanks to thick Messinian evaporites, has resulted in the construction, and the accelerated southward growth, of the two, subdued and wide, MR Ionian and Levantine outer domains. 


\section{The Tyrrhenian Sea: an example of a land-locked back-arc basin}

\subsection{Geodynamic setting}

Between the Neogene Western Mediterranean basin and the Mesozoic Ionian and Levantine basins (Biju Duval et al., 1978), the Tyrrhenian Sea (fig. 6) consists in a small triangular marine basin, surrounded by Corsica, Sardinia, Sicily, and peninsular Italy. The Tyrrhenian lies to the back of a subduction-volcanic-arc system (the Calabrian arc) and inside successive collision zones, still active in the
Central-Northern Apennines and Calabrian arc.

Today, the Tyrrhenian Sea (figs. 6 and 7) includes a deep central basin, reaching a depth of $3600 \mathrm{~m}$ in its northwestern corner and surrounded by narrow continental shelves and relatively steep continental slopes. The northwestern part of the basin, the Magnaghi-Vavilov domain, contains two large submarine volcanoes: the Magnaghi volcano at the base of the Sardinian margin, and the Vavilov volcano whose top reaches a depth of $684 \mathrm{~m}$ The southeastern part of the basin (Marsili) is bisected by the Marsili seamount, the largest volcano within the Tyrrhenian Sea, culminating at $505 \mathrm{~m}$ water depth.

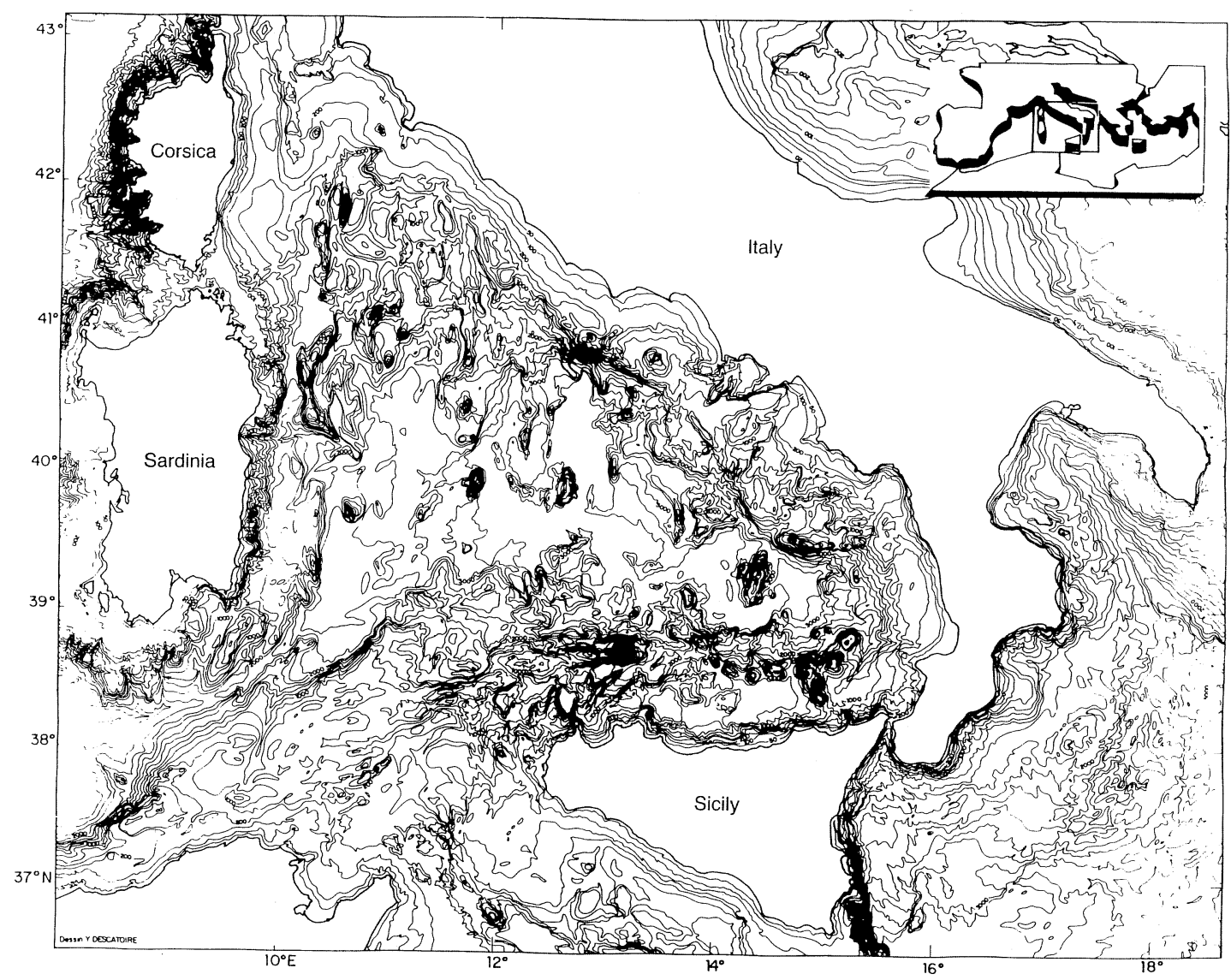

Fig. 6. Bathymetry of the Tyrrhenian Sea and surrounding area (contour interval $200 \mathrm{~m}$ ); from international chart of Mediterranean Intergovernmental Oceanographic Commission (UNESCO). 


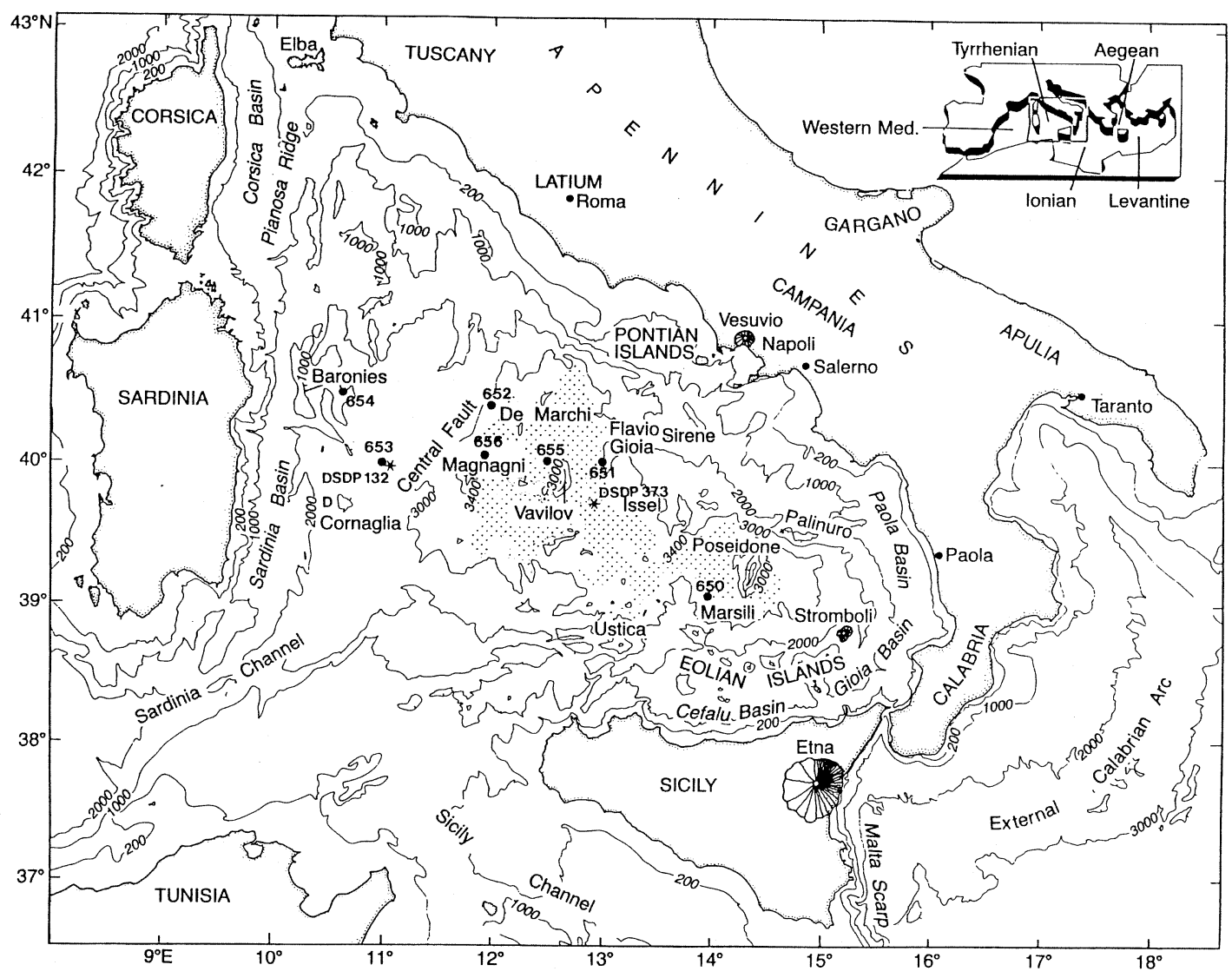

Fig. 7. Simplified bathymetry sketch of the Tyrrhenian (200, 1000, 2000, $3000 \mathrm{~m}$ bathymetric lines); principal terms used in this paper and location of ODP 107 sites and of DSDP site 373.

A sketch map of the Moho depth (Réhault et al., 1987b) clearly shows two domains, with a depth less than $10 \mathrm{~km}$ and a crustal thickness of less than $7 \mathrm{~km}$ beneath the MagnaghiVavilov basin and the Marsili basin.

Under the adjacent bordering Ionian Sea, the Moho has been documented at $20 \mathrm{~km}$ depth (Finetti, 1982). From this area, it dips northwestward, beneath the external Calabrian arc, reaching $35 \mathrm{~km}$ depth immediately southeast of Calabria. Under Southern Italy, seismic data indicate crustal superposition of an upper Tyrrhenian-Calabrian Moho (between 15 and $20 \mathrm{~km}$ ) over the Ionian Moho, about $40 \mathrm{~km}$ deep (Morelli et al., 1975; Schütte, 1978).
In the Tyrrhenian, the distribution of seismicity delineates a Benioff zone dipping from the Ionian Sea toward the northwest, beneath the central basin. The deepest foci are found around $500 \mathrm{~km}$ in depth, beneath the Eastern Vavilov basin. In both the Tyrrhenian Sea and Calabria, earthquake focal mechanisms indicate a generally extensional stress field together with strike-slip components. Compressional events in coincidence with the northern and southwestern extremities of onshore main thrust zones, characterize the Sicilian and Apenninic borders (Ghisetti and Vezzani, 1981; Gasparini et al., 1982; Moussat, 1983; Moussat et al., 1985; Boccaletti et al., 1984). 
Within the Tyrrhenian Sea, a clear contrast exists between the central plain, characterized by strong magnetic anomalies, and most of the margins where magnitudes are low (Réhault et al., 1987b). «Oceanic-type» magnetic pattern can only tentatively be recognized in the Marsili basin. Moussat (1983), however, believes that magnetic anomalies offer two main trends: a $\mathrm{N} 10^{\circ}-30^{\circ}$ direction along the Sardinia margin and over parts of the Vavilov area and within the Marsili basin; a $\mathrm{N} 110^{\circ}-120^{\circ}$, less clear trend is expressed by lineaments at the foot of the Northern Sicilian margin and along some parts of the Sardinian margin.

\subsection{The Tyrrhenian margins}

Numerous seismic reflection data are available within the Tyrrhenian Sea; they made it possible to briefly outline the main geological structures of its margins and central domain.

- Off Sardinia, the upper slope is intensively cut by dominantly east-trending canyons (figs. 6 and 7) and north-trending basement ridges which correspond to symmetrical horst structures, and asymmetrical blocks, tilted either landward or seaward (fig. 8). Towards the east, the middle slope (or Cornaglia Terrace) is abruptly bounded by a series of east-facing scarps trending $\mathrm{N} 30^{\circ}$, known as the Central Fault (Selli and Fabbri, 1971). From this area the seafloor steps down more than $1000 \mathrm{~m}$ to the lower margin. At the foot of the Central Fault scarps the lower margin extends as a domain of narrow basins and structural blocks trending $\mathrm{N} 10^{\circ} \mathrm{E}$ in average. Some of these blocks are overlain by dipping and wedging seismic units (fig. 8); as on the upper Sardinian margin, these units have been referred as related to tilting of fault-bounded blocks (Moussat et al., 1985; Réhault et al., 1987a). Finally, two seamounts, the Monte de Marchi and the Monte Farfalle, (figs. 6 and 7) stand as much as $1.4 \mathrm{~km}$ above surrounding ponded turbidities. These basement ridges, which lie just west of the inferred transition from continental to oceanic-type Vavilov basin crusts (fig. 8), are cut by $\mathrm{N} 10^{\circ}-30^{\circ} \mathrm{E}$, almost vertical, major fault scarps and transverse subtle open fractures (Gennesseaux et al., 1986).

- The Apenninic margin (fig. 6) is comparably bounded by asymmetric highs where continental rocks have also been observed during submersible dives and sampled by dredging (Dal Piaz et al., 1983). A similar water depth $(2500 \mathrm{~m})$, the presence of thickly sedimented basins, and the inferred presence of Messinian evaporites, call for strong analogies with the conjugate Sardinian margin.

- South of Salerno, off Campania (figs. 6 and 7), the continental margin is controlled by two structural trends; a west-northwest direction, marked by elongated scarps and highs, and northeast trends expressed in a series of basement highs, scarps, and linear canyons. The slope promontory, which forms a thickcrusted ridge between Vavilov and Marsili basins (figs. 7 and 9) appears itself cut into a series of horsts, including Monte Issel and Monte Poseidone.

- Off Western Calabria, the margin comprises upper slope basins filled by thick ponded sediment sequences (as thick as $5 \mathrm{~km}$ ) referred to be Pliocene-Pleistocene turbidities (Barone et al., 1982).

- Comparable slope basins extend along the upper Sicilian margin. Dammed downslope by the Eolian Islands arc system (figs. 6 and 7), they contain Messinian evaporitic sequences confined to restricted depressions.

- The Eolian volcanic arc comprises seven merging volcanoes (fig. 7). Geochemical analyses of lavas obtained on these features show both calc-alkaline series and shoshonitic suites; radiometric ages indicate dominant volcanic activity during the Pleistocene (Barberi et al., 1974).

\subsection{The central basins}

The Vavilov basin is a flat-floored triangular-shaped basin, with water depths greater than $3500 \mathrm{~m}$, bounded by the Vavilov volcano to the south. From seismic data the basin appears as a thickly sedimented plain with a sedimentary fill attributed to Pliocene-Pleistocene turbiditic sediments (fig. 8).

DSDP Site 373, located southeast of Vavilov volcano (fig. 7), has yielded oceanic-type 


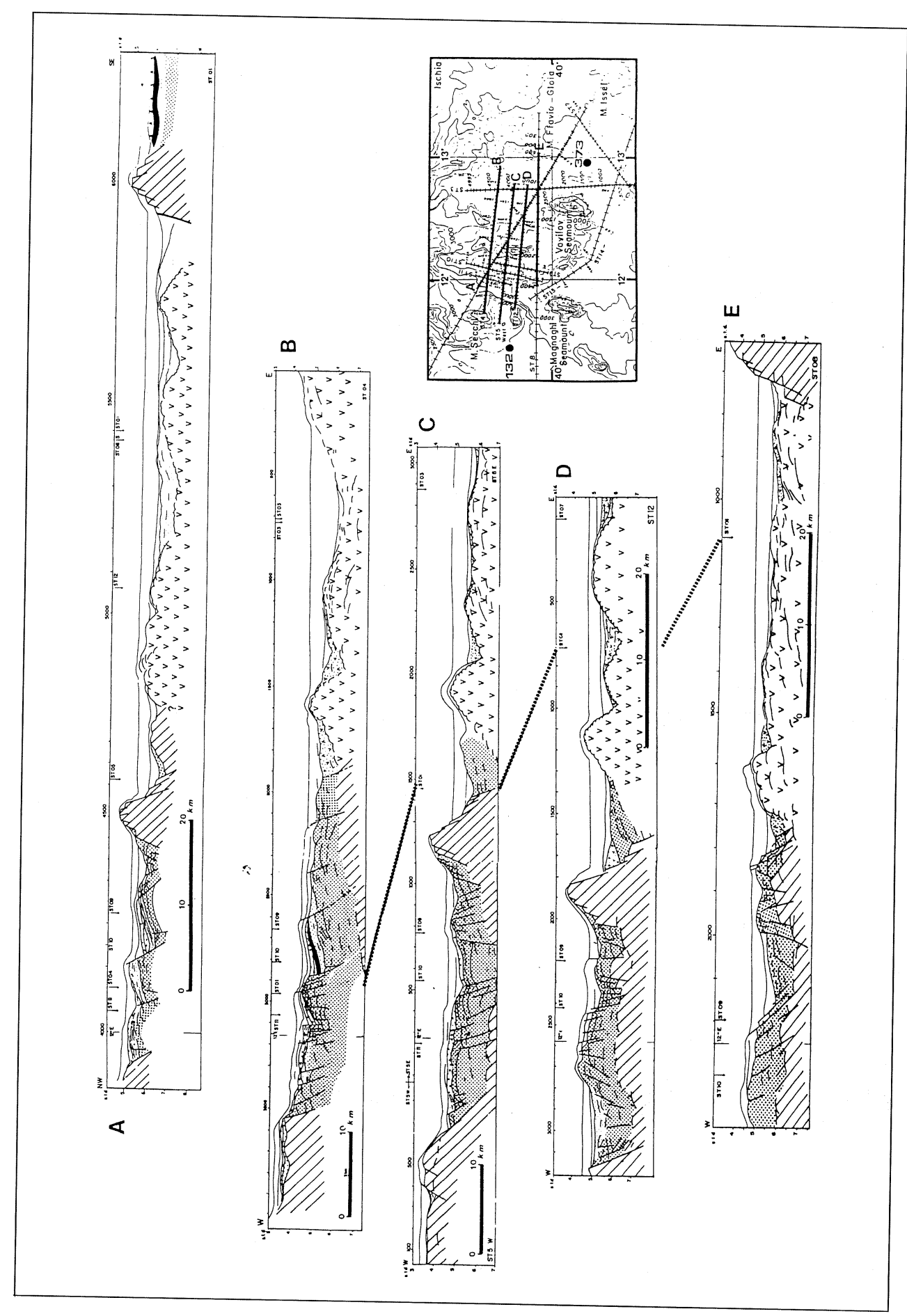

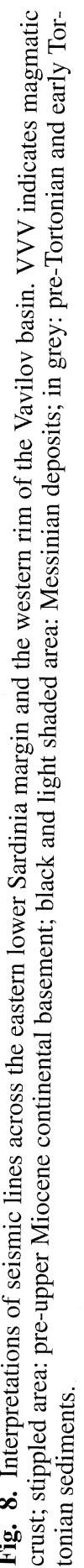


tholeiites (Dietrich et al., 1978; Barberi et al., 1973) and dredging along the volcano as well as on the Magnaghi seamount, have provided transitional-type basalts (Selli and Fabbri, 1971; Fabbri and Selli, 1972) dated around 2.7 Ma for Magnaghi seamount.

Locked between peninsular Italy and Sicily, the deep and flat-floored Marsili basin has an almost rhombohedral shape; like the Vavilov basin it is bisected by a huge, elliptical volcano, trending approximately $\mathrm{N} 15^{\circ} \mathrm{E}$ and standing $3000 \mathrm{~m}$ above the bathyal plain (fig. 7). Dredge stations near the top of the volcano have recovered calc-alkaline rocks of very recent age (0.2 Ma) (Selli et al., 1977).

Seismic lines across the Marsili basin show numerous interbedded lava flows near the volcano flanks; along its western margin dipping reflectors, covered by a thin layer of subhorizontal reflectors, have been interpreted as tilted sedimentary sequences related to recent extensional phases (Mascle and Réhault, 1990).

\subsection{Scientific drilling geological contraints}

Following Leg DSDP 42 (Hsü, Montadert et al., 1978), Leg ODP 107 (Kastens, Mascle et al., 1987, 1990) has brought crucial data to better understand the rifting and magmatic processes (and chronology) that were operating in the Tyrrhenian Sea.

In Tortonian times rifting was underway in the area that now corresponds to the upper Sardinian margin. This rifting has been well demonstrated by documenting the subsidence and tilting of fault-bounded crustal blocks. The base of hole 654A (fig. 9) recorded a transgressive sequence evolving from subaerial conglomerate to shallow water sand and to open marine ooze. Benthic foraminifers indicate that water depth progressively increased upsection from shallow to a few hundred meters in late Tortonian. Clay mineralogy also evolves upsection from an assemblage derived from erosion of fresh crystalline rocks to an assemblage derived from soil (Chamley et al., 1990). Since the base of this hole reached a syn-rift landward-dipping wedge of sediments (Mascle and Réhault, 1990), the drilled section can be clearly correlated to rifting-related tectonic subsidence.

During the Messinian, continuous rifting extension and subsidence persisted on the Sardinia margin; the numerous microfaults recorded in the sediments of Site 654 and of Site 652 attest to intense extensional tectonic activities during this time span (Kastens, Mascle et al., 1987).

In the same period, tilting was also active on fault block on the lower Sardinia margin; in Site 652 (fig. 9), the base of the synrift sediments correlates to a barren Messinian section (Mascle and Réhault, 1990; Kastens, Mascle et al., 1988) whose sediments fine upsection as expected in a deepening and broadening basin. Near the end of the Messinian, tilting may have slowed or even stopped on the upper margin (Site 654), while it persisted throughout the Messinian at Site 652, as shown by the synrift/post-rift contact which lies within the Pliocene section (Mascle and Réhault, 1990; Kastens, Mascle et al., 1988).

The Pliocene was also characterized by a persisting subsidence all along the circumTyrrhenian margins (Selli and Fabbri, 1971). As an example benthic assemblages from Sites 653 and 654 (upper Sardinia margin) indicate lower epibathyal depths (800-1200 m water depth) in the early Pliocene and a gradual subsidence to approximately a water depth of $2000 \mathrm{~m}$ at the Pliocene-Pleistocene boundary (Colalongo et al., 1990; Hasegawa et al., 1990). Seismic stratigraphy correlations suggest that strong Pliocene subsidence also occurred on the Sicilian margin, on the margin of peninsular Italy, as well as on the Sardinian margin.

There is little evidence for Messinian age vulcanism within the Vavilov or Marsili basins although vulcanism in the circum-Tyrrhenian region was active at this time. For example, Site 654 Messinian sediments contain only a few tephra layers whose source has not been clearly identified (McCoy and Cornell, 1990).

In the Tyrrhenian, basaltic crust formation was widespread during the Pliocene. At Site 651 , basaltic volcanism has been recorded as a multistage process: basalt flows were first 


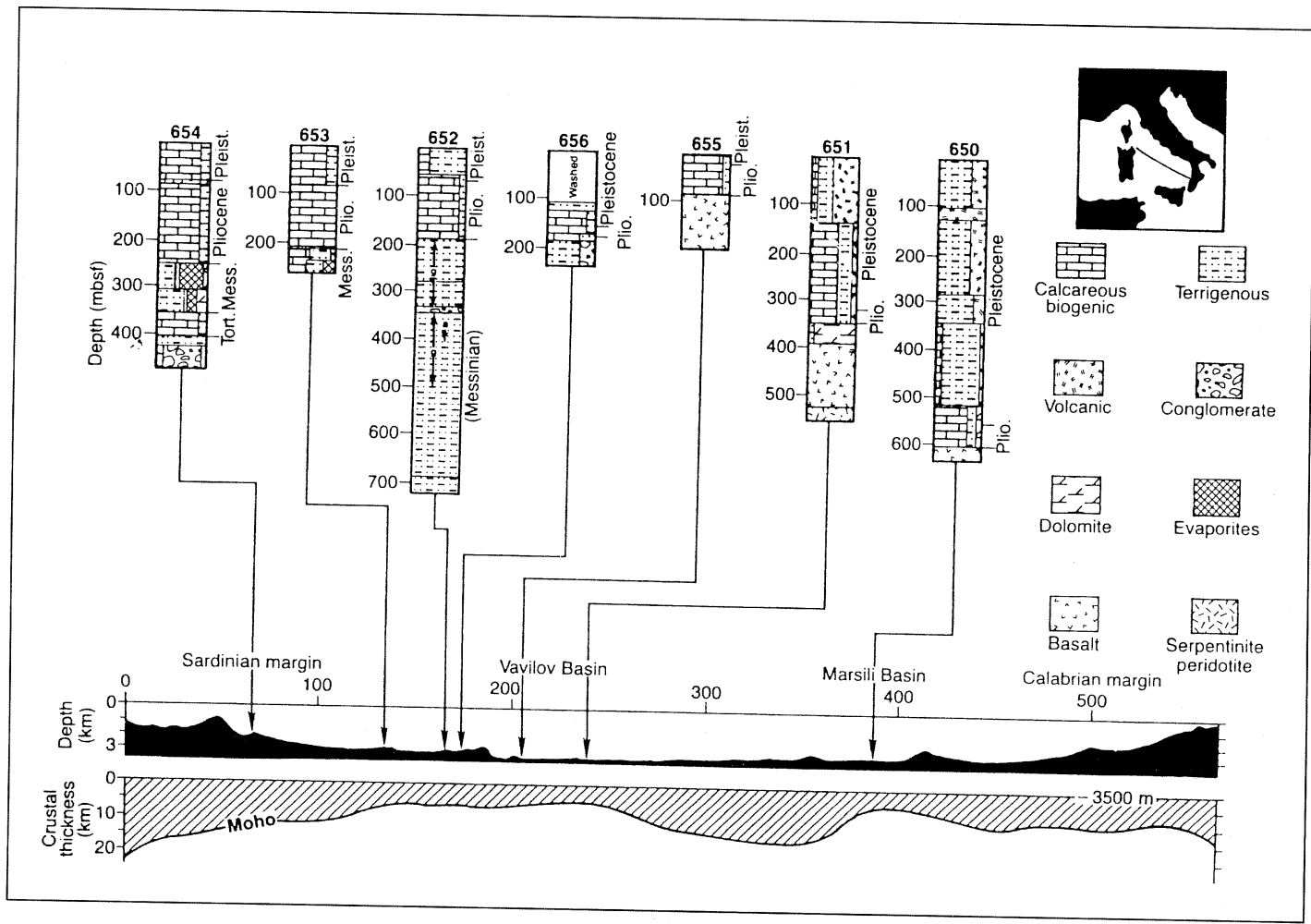
Fig. 9. Simplified lithological columns of ODP sites 107 projected along a NW-SE morphological and crustal
section across the Tyrrhenian Sea.

erupted and doleritic sills later on intruded the sediments and metamorphosed both the sediments and the basalt flows (Beccaluva et al., 1990). Vavilov and Magnaghi volcanos erupted during the late Pliocene (Savelli, 1988).

Vavilov basin basalts span a wide range of chemistry. At Site 655 (fig. 9) a transitional mid-ocean ridge basalt (T-MORB) flow was recovered (Beccaluva et al., 1990). Older basalt flows are alkalic, whereas younger basalts (at Site 651) show calc-alkaline affinities. The mantle, from which Site 651 basalts were derived, may have well contained fluids released from the southern subducting slab (Bertrand et al., 1990). At DSDP Site 373, two different basalt suites were sampled; lowtitanium samples, similar to high-aluminium tholeiites (Dietrich et al., 1978), interbedded with high titanium samples similar to Site 655 tholeiites (Beccaluva et al., 1990). Finally, Vavilov and Magnaghi seamounts erupted, in late Pliocene, alkalic (Robin et al., 1987) to tholeiitic basalts (Savelli, 1988).

During, or just before the early Pliocene, a body of peridotite was emplaced in the crust of the Vavilov basin (Site 651). Bonatti et al. (1990) believe that this peridotite might be residual mantle material from which island arc and/or back-arc calc-alkaline basalts were melted out.

In the Marsili basin, basaltic crust formation began later, only toward the end of the Pliocene, at approximately $2 \mathrm{Ma}$. The Marsili basin basalt (Site 650) is highly altered but shows calc-alkaline affinities (Beccaluva et al., 1990); its strong vesicularity has been consid- 
ered as evidence that the basin was created at a much shallower depth than its present $4100 \mathrm{~m}$ depth (Kastens, Mascle et al., 1988).

During the Pliocene, subalkalic and alkalic basaltic volcanism was widespread on Sardinia; thin basalt flows, cored at Site 654 just below the Pliocene-Pleistocene boundary bear a petrochemistry similar to coeval Sardinia intraplate tholeites (Beccaluva et al., 1990).

On the upper Sardinia margin, subsidence slowed down, or even stopped, by Pleistocene time; benthic foraminifers from Site 654 indicate water depths around $2000 \mathrm{~m}$ throughout the Pleistocene (Colalongo et al., 1990). By contrast, tectonic and magmatic activity was focused in the south eastern end of the Tyrrhenian, in and around the Marsili basin at that time. The Marsili basin edificated probably as a consequence of east-southeast horizontal extension, at a rate between 3 to $4 \mathrm{~cm} / \mathrm{yr}$; its floor subsided rapidly, may be in excess of $700 \mathrm{~m} / \mathrm{m} . \mathrm{y}$. Finally, the Marsili volcano grew to dominate the basin, erupting tholeiitic basalts early in its history and capping them off with calc-alkaline basalt near its summit (Selli et al., 1977; Savelli, 1988).

In the Tyrrhenian Sea, Pleistocene volcanic activity was widespread. The calc-alkaline and shoshonitic Eolian Island volcanic arc is believed to be a Pleistocene construction (Beccaluva et al., 1981). The volcanic fields near Rome and Naples began erupting a distinctive suite of potassium-rich magmas, while Mt. Etna, on Sicily, erupted alkaline magmas (Savelli, 1988). Elsewhere in the Tyrrhenian, eruptions continued on Vavilov volcano well into the Pleistocene.

\subsection{Discussion}

According to ODP drillings and geophysical data, the geological evolution of the Tyrrhenian has been summarized in several phases and according to different interpretations (Kastens and Mascle, 1990) is still matter of discussion:

a) An extensional basin formed since the late Miocene within a thickened continental crust resulting from former orogens (Sartori, 1990). This juxtaposition of extension in the
Tyrrhenian and compression in the circumTyrrhenian, tends to favor a model of extensional collapse of an overthickened continental lithosphere as proposed for example for the Alboran sea (Platt and Vissers, 1989).

b) A major rifting phase probably initiated during the Tortonian. Rifting initiation may have been coeval with changes in the direction of Africa-Europe relative motion; it has been shown that a decrease in obliquity of convergence between two plates may cause an increase in the component of convergence perpendicular to the subduction trench and may thus favor back-arc extension (Fein and Jurdy, 1986).

c) Creation of basaltic crust in the northern of the two Tyrrhenian basins (Vavilov basin) clearly occurred earlier than in the southern one (Marsili basin). This can be potentially explained in terms of «rollback» of the subducting Ionian lithosphere (Kastens, Mascle et al., 1988) (fig. 10).

d) Extension has been diachronous across the Sardinia margin; subsidence and faultbounded crustal block rotation occurred earlier on the upper margin than on the lower one; on this margin rifting was completed much more quickly than at classic divergent margins bordering major oceans. This might be interpreted in terms of asymmetrical development above an eastward dipping detachment fault or as a consequence of faults driven by rollback of the hinge zone of the Ionian subducting slab (Kastens, Mascle et al., 1988).

e) The Marsili basin formed during the latest Pliocene and Pleistocene with a subsidence rate that was much faster than that classically observed for young oceanic type crust. Such rapid evolution may result from the very small size of the basin and short length of the «spreading center». Thermal conduction perpendicular to the basin direction of extension may have cooled the newly accreted lithosphere more quickly than predicted by models proposed for standard mid-ocean ridge systems (Rosencrantz et al., 1988).

f) A shallow peridotite body was emplaced, under thin basalts, in the Vavilov basin. This body is not the remnant of Alpine ophiolites, but a fragment of refractory mantle material 


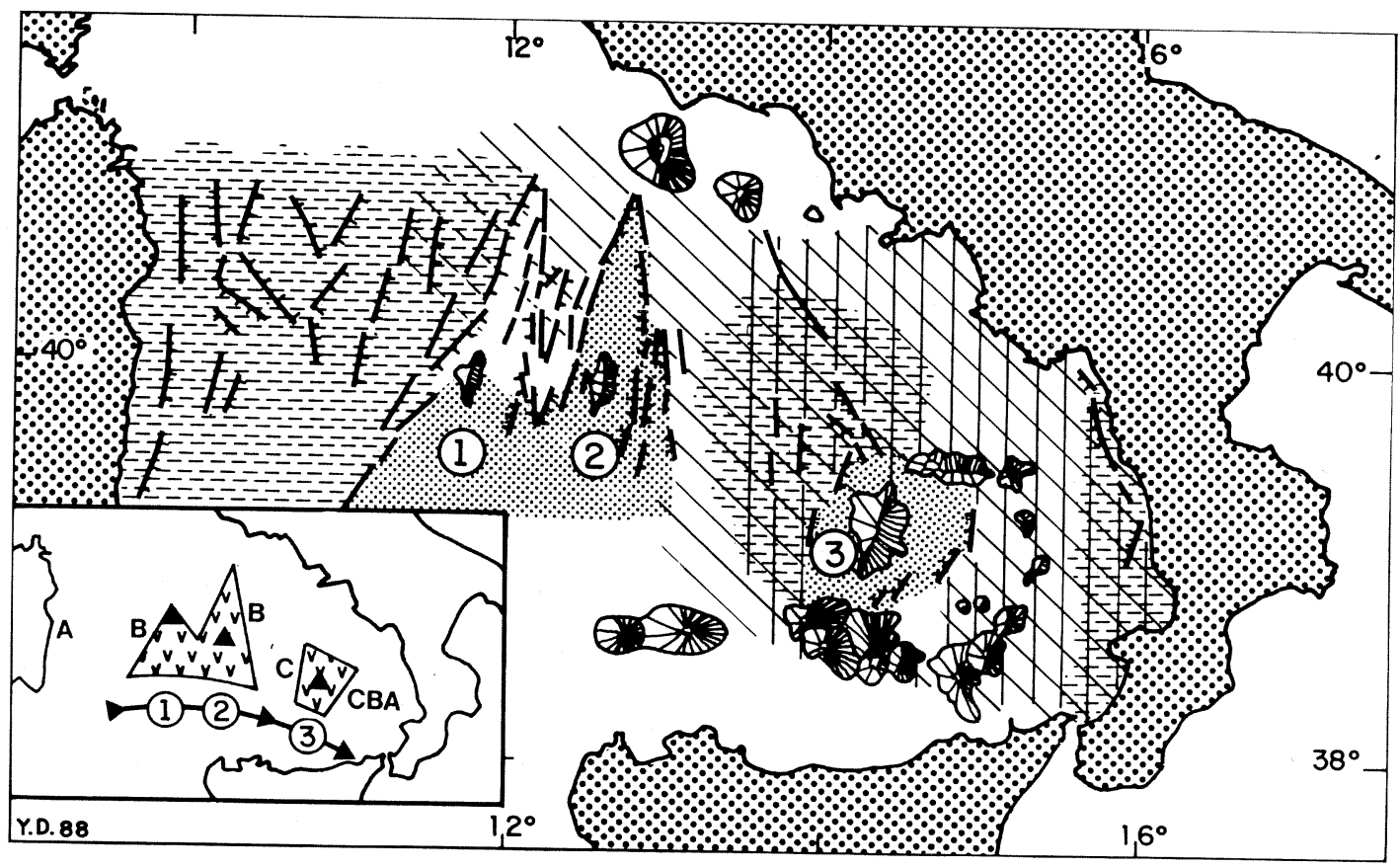

Fig. 10. Structural sketch of the Central Tyrrhenian (after Mascle and Réhault, 1990) showing the main structures of the margin and deep basins. 1, 2, 3 for the Magnaghi, Vavilov and Marsili basins respectively; light dots for oceanic-magmatic basin; broken lines for upper Tortonian rifting; oblique lines for Messinian rifting phase; vertical lines for Pliocene-Pleistocene extensional phase. Insert: migration towards SE of rifting phases and successive magmatic basins creation. A, B, C show margin areas submitted to Tortonian, Messinian and Plio-Pleistocene rifting episodes respectively.

from which a calc-alkaline basaltic magma was removed under hydrous conditions (Bonatti et al., 1990). Timing and mechanism of emplacement of this mantle material into a shallow crust are still unclear; unroofing by deeply penetrating detachement faults must be considered as a possible mechanism (Kastens, Mascle et al., 1988).

\section{Conclusions}

Today the Mediterranean Sea represents an almost unique example of incipient continental collision between two major plates.

This phenomenon leads to the creation of small extensional basins, such as the Tyrrhe- nian and of large-scale tectonized accretionary complexes such as the Mediterranean Ridge. Most of the structural characteristics from both features indicate important changes of tectonic styles around the late Miocene. Thus, in the Mediterranean, the Tortonian to Messinian time span appears be a key period, marked first by a wide spread extension episode, superimposed on previous collisional features both within the Tyrrhenian and Aegean domains. In the Messinian, this active rifting allowed to trap important thickness of evaporitic sequences in evolving extensional features. In the same time, thick evaporites were accumulating in most of the deep oceanic Mediterranean basins, including the Ionian and Levantine areas. The presence of this ductile and weak ma- 
terial has drastically modified the style of tectonic processes within the Mediterranean Ridge and probably in the External Calabrian Arc.

If the direction and average velocity of the relative motion between Africa and Europe remain stable over time, it is likely that most of the present-day submarine Mediterranean domains will be considerably modified within the next 10 to $15 \mathrm{My}$. For example, and as already suggested by Finetti (1976), the still submerged Mediterranean Ridge would become a new mountain chain between Eastern North Africa and Southern Aegean. The rheological characteristics of Messinian deposits imply that these sediments will necessarily play a prominent part in the resulting structural pattern, in a manner somewhat similar to that of the German Triassic sediments during previous alpine collision episodes.

\section{Acknowledgements}

This synthetic paper results from the detailed works of many scientists and technicians. It has greatly benefited from discussions during and after a workshop dedicated to the «Geodynamics of the Mediterranean Area and Implications on Volcanic and Seismic Hazards» held in Siena in April 1996. Thanks are due to Prof. E. Mantovani and to two reviewers who greatly improved an early version of this paper.

Contribution number 99 of Géosciences Azur - UMR 6526 (CNRS - UPMC - UNSA ORSTOM).

\section{REFERENCES}

BArberi, F., P. GASPARini, F. InNOCEnTI and L. Villari (1973): Volcanism of the Southern Tyrrhenian Sea and its geodynamic implications, J. Geophys. Res., 23, 5221-5232.

Barberi, F., F. Innocenti, G. Ferrara, J. Keller and L. VILlLARI (1974): Evolution of Eolian arc volcanims (Southern Tyrrhenian Sea), Earth Planet. Sci. Lett., 21, 269-276.

BArone, A., A. FAbbri, S. Rossi and R. SARTORI (1982): Geological structure and evolution of the marine areas adjacent to Calabrian arc, Earth Evol. Sci., 3, 207-221.
Beccaluva, L., G. Gabbianelli, F. Lucchint, P.L. Rossi, C. SAVelli and O. ZedA (1981): Magnetic character and K/Ar ages of volcanics dredged from the andolian seamounts (Tyrrhenian Sea), in Sedimentary Basins of Mediterranean Margins, edited by F.G. WEZEL (Tecnoprint, Bologna), 361-168.

Beccaluva, L., E. Bonatti, C. Dupuy, G. Ferrara, F. Innocenti, F. Lucchini, P. Macera, R. Petrini, P.L. Rossi, G. SERri, M. SEYLER and F. SienA (1990): Geochemistry and mineralogy of volcanic rocks from ODP sites 650, 651, 655 and 654 in the Tyrrhenian Sea, in Kastens, K.A., Mascle, J., et al., 1990, Proc. ODP, Sci. Results, 107, College Station, TX (Ocean Drilling Program), 49-74.

Belderson, R.H., N.H. KenYon and A.H. Stride (1978): Local submarine salt-karst formation on the Hellenic outer ridge, Eastern Mediterranean, Geology, 6, 716-720.

Bertrand, H., P. Boivin and C. Robin (1990): Petrology and geochemistry of basalts from the Vavilov basin (Tyrrhenian Sea), Ocean Drilling Program Leg 107, Holes 651A and 655B, in KASTENS, K.A., MASCLE, J., et al., 1990, Proc. ODP, Sci. Results, 107, College Station, TX (Ocean Drilling Program), 75-98.

Biju-Duval, B., J. Letouzey and L. Montadert (1978): Structure and evolution of the Mediterranean basins, in Hsü, K., Montadert, L., et al., Init. Repts. DSDP, 34, Washington (US Govt. Printing Office), 951-984.

BocCAletTI, M., R. NiCOlich and L. TORTORICI (1984): The Calabrian arc and the Ionian Sea in the dynamic evolution of the Central Mediterranean, Mar. Geol., 55, 219-245.

Boillot, G., L. Montadert, M. Lemoine and B. BijuDuval (1984): Les Marges Continentales Actuelles et Fossiles Autour de la France (Masson, Paris).

Bonatti, E., M. Seyler, J. Channell, J. Giraudeau and G. MASClE (1990): Peridotites drilled from the Tyrrhenian Sea, ODP Leg 107, in KASTENS, K.A., MASCLE, J., et al., 1990, Proc. ODP, Sci. Results, 107, College Station, TX (Ocean Drilling Program), 37-47.

Camerlenghi, A., M.B. Cita, W. Hieke and T. RiCCHIUTO (1992): Geological evidence for mud diapirism on the Mediterrranean ridge accretionary complex, Earth Planet. Sci. Lett., 109, 493-504.

Chamley, H., P. Debrabant, C. Robert, G. Mascle, J.P. RÉhault and J. Aprahamian (1990): Mineralogical and geochemical investigations on lates Miocene deposits in the Tyrrhenian Sea (ODP Leg 107), in KASTEns, K.A., Mascle, J., et al., 1990, Proc. ODP, Sci. Results, 107, College Station, TX (Ocean Drilling Program), 153-167.

Chaumillon, E. (1995): Structure de la Ride Méditerranéenne: apports de la sismique multitrace, Thèse de Doctorat, Université Pierre et Marie Curie, Paris VI.

Chaumillon, E. and J. Mascle (1995): Variations latérales des fronts de déformation de la Ride Méditerranéenne, Bull. Soc. Géol. Fr., 166, 463-478.

Chaumillon, E. and J. Mascle (1997): From foreland to forearc domains: new multichannel seismic reflection survey of the Mediterranean ridge accretionary complex (Eastern Mediterranean), Mar. Geol. (in press).

Chaumillon, E., J. Mascle and J. Hoffmann (1996): 
Deformation of the Western Mediterranean ridge: importance of evaporitic formations, Tectonophysics, 263, 163-190.

CitA, M.B., W.B.F. Ryan and L. PAGgi (1981): Prometheus mud breccia. An example of shale diapirism in the Western Mediterrranean ridge, Ann. Géol. Pays Héll., 30, 543-569.

Colalongo, M.L., G. Pasini, A. Poluzzi and R. SPROVIERI (1990): Relationship between the benthic forminifers and the ostracodes in Pliocene-Pleistocene Tyrrhenian deep-sea record (ODP Leg 107, Site 654), in Kastens, K.A., Mascle, J., et al., 1990, Proc. ODP, Sci. Results, 107, College Station, TX (Ocean Drilling Program), 479-492.

Dal Piaz, G.V., A. Del Moro, B. Sabatino, R. Sartori and C. SAVelli (1983): Geologica del Monte Flavio Gioia (Tirreno Centrale), Mem. Sci. Geol, 35, 429-452.

De Voogd, B., C. Truffert, N. Chamot-Rooke, P. HuCHON, S. Lallemant and X. Le Pichon (1992): Twoship deep seismic soundings in the basins of the Mediterranean Sea (Pasiphae cruise), Geophys. J. Int., 109, 536-552.

Dietrich, V., R. Emmerman, H. Puchelt and J. Keller (1978): Oceanic basalt from the Tyrrhenian basin: DSDP Leg 42A, Hole 373A, in Hsü, K., MontaderT, L. et al., Init. Repts. DSDP, 42 (Pt.1), Washington (US Govt. Printing Office), 515-530.

FABBRI, A. and R. SELLI (1972): The structure and stratigraphy of the Tyrrhenian Sea, in The Mediterranean Sea, a Natural Sedimentation Laboratory, edited by D.J. StAnley, Stroudsburg, PA (Dowden, Hutchinson, Ross), 75-81.

FEIN, J.B. and D.M. JuRDY (1986): Plate motion controls on back-arc spreading, Geophys. Res. Lett., 13, 456-459.

FINETTI, I. (1976): Mediterranean ridge: a young submerged chain associated with the hellenic arc, Boll. Geofis. Teor. Appl., 13, 31-65.

FINETTI, I. (1982): Structural, stratigraphy and evolution of Central Mediterranean, Boll. Geofis. Teor. Appl., 24 (96), 247-312.

Foucher, J.P., N. Chamot-Roocke, S. Alexandry, J.M. Augustin, S. Monti, P. Pavlakis and M. Voisset (1993): Multibeam bathymetry and seabed reflectivity maps of the MEDRIFF corridor across the Eastern Mediterranean ridge, in EUG (VII), Strasbourg, France, edited by T. Cognita (Blackwell Scientific Publication), 278-279.

Gasparini, C., I. Iannaconne, P. Scandone and R. SCARPA (1982): Seismotectonics of the Calabrian arc, Tectonophysics, 84, 267-286.

Gennesseaux, M., J.P. Réhault, B. Thomas, P. Colantoni, A. FAbBri, C. Lepvrier, G. Mascle, A. MaufFret, R. Polino, C. Robin and J.R. VAnNey (1986): Résultats des plongées en submersible Cyana sur les blocs continentaux basculés et le volcan Vavilov (Mer Tyrrhénienne Centrale), C. R. Acad. Sci. Ser., 2 (12), 785-792.

GhisetTi, F.A. and L. VezZANi (1981): Contribution of structural analysis to understanding the geodynamic evolution of the Calabrian arc (Southern Italy), $J$. Struct. Geol., 3 (4), 371-381.

Hasegawa, S., R. Sprovieri and A. Poluzzi (1990):
Quantitative analysis of benthic foraminiferal assemblages from Plio-Pleistocene sequences in the Tyrrhenian Sea, ODP Leg 107, in KASTEns, K.A., MASCle, J., et al., 1990, Proc. ODP, Sci. Results, 107, College Station, TX (Ocean Drilling Program), 461-478.

HsÜ, K. and L. MONTADERT et al. (1978): Initial Reports of the Deep Sea Drilling Project, vol. 42, part 1, Washington (U.S. Government Printing Office).

HuChON, P., N. Lyberis, J. ANGEliER, X. Le PiCHON and V. RenARD (1982): Tectonics of the Hellenic trench: a synthesis of seabeam and submersible observations, Tectonophysics, 86, 69-112.

KASTENS, K.A. (1991): Rates of outward growth of the Mediterrranean ridge accretionary complex, Tectonophysics, 199, 25-50.

KASTENS, K. and J. MASCLE (1990): The geological evolution of the Tyrrhenian Sea: an introduction to the scientific results of ODP Leg 107, in KASTENS, K.A., MASCLE, J., et al., 1990, Proc. ODP, Sci. Results, 107, College Station, TX (Ocean Drilling Program), 13-26.

Kastens, K.A. and J. MASCle et al. (1987): Proc. ODP, Init. Repts., 107, College Station, TX (Ocean Drilling Program).

KASTENS, K. and J. MASClE et al. (1988): ODP Leg 107 in the Tyrrhenian Sea: insights into passive margin and back-arc basin evolution, Geol. Soc. Am. Bull., 100, 1140-1156.

Kastens, K.A. and J. MAscle et al. (1990): Proc. ODP, Sci. Results, 107, College Station, TX (Ocean Drilling Program).

Kastens, K.A., A.B. NAnCY and M.B. CitA (1992): Progressive deformation of an evaporites-bearing accretionary complex: Sea-Marc I, Sea-Beam and Piston core observations from the Mediterrranean ridge, Mar. Geophys. Res., 14, 249-298.

KenYON, N.H., R.H. Belderson and A.H. STRIDE (1982): Detailed tectonic trends on the central part of the Hellenic outer ridge and in the Hellenic trench system, Geol. Soc. London, 10, 335-343.

Lallemant, S.J., C. Truffert, L. Jolivet, P. Henry, N. Chamot-Rooke and B. De Voogd (1994): Spatial transition from compression to extension in the Western Mediterranean ridge accretionary complex, Tectonophysics, 234, 33-52.

Le Pichon, X. and J. Angelier (1979): The Hellenic arc and trench system: a key to the neotectonic evolution of the Eastern Mediterranean region, Tectonophysics, 60, 1-42.

Le Pichon, X., N. Lybéris, J. Angelier and V. Renard (1982): Strain distribution over the East Mediterrranean ridge: a synthesis incorporating new Sea-Beam Data, Tectonophysics, 86, 243-274.

Le Pichon, X., N. Chamot-Roocke and S. Lallemant (1995): Geodetic determination of the kinematics of Central Greece with respect to Europe: implications for Eastern Mediterranean Tectonics, J. Geophys. Res., 100, 12675-12690.

LiMONOV, A.F., J.M. WoOdsIDE and M.K. IVANOV (1994): Mud Volcanism in the Mediterranean and Black Seas and Shallow Structure of the Eratosthenes Seamount, UNESCO reports in marine science 64: initial results of the geological and geophysical investigations during 
the third UNESCO-ESF «training-through-research» Cruise of RV Gelendzhik (June-July 1993).

Limonov, A.F., J.M. Woodside, M.B. CitA and M.K. IVANOV (1996): The Mediterranean ridge and related mud diapirism: a background, Mar. Geol., 132, 7-19.

MAKRIS, J. (1976): A dynamic model of the Hellenic arc deduced from geophysical data, Tectonophysics, 36, 339-346.

Makris, J. and C. Stobbe (1984): Physical properties and state of the crust and upper mantle of the Eastern Mediterranean Sea deduced from geophysical data, Mar. Geol., 55, 347-363.

Mascle, J. and J.P. RéHault (1990): A revised seismic stratigraphy of the Tyrrhenian Sea: implications for the basin evolution, in KaStens, K.A., MASCle, J., et al., 1990, Proc. ODP, Sci. Results, 107, College Station, TX (Ocean Drilling Program), 617-636.

Mascle, J., E. Chaumillon, J. Hoffmann and J.P. RéHAULT (1994): Premiers résultats de la campagne de sismique réflexion multitrace PRISMED à travers la branche Ionienne de la Ride Méditerranéenne, $C . R$. Acad. Sci. Ser., 318, 651-657.

McCoy, F.W. and W. CoRNell (1990): Volcaniclastic sediments in the Tyrrhenian basin, in KASTENS, K.A., Mascle, J., et al., 1990, Proc. ODP, Sci. Results, 107, College Station, TX (Ocean Drilling Program), 291-305

Morelli, C., P. Giese, R. Cassinis, B. Colombi, I. Guerra, G. LuOngo, S. ScArascia and K.G. SCHUTTE (1975): Crustal structure of Southern Italy; a seismic refraction profile between Puglia-CalabriaSicily, Boll. Geofis. Teor. Appl., 17, 183-210.

Moussat, E. (1983): Evolution de la Mer Tyrrhénienne Centrale et Orientale et de ses marges septentrionales en relation avec la néotectonique dans l'arc Calabrais, Thesis, Univ. Pierre et Marie Curie, Paris.

Moussat, E., J.P. RÉhault, A. Fabbri and G. Mascle (1985): Evolution géologique de la Mer Tyrrhénienne, C. R. Acad. Sci. Ser., 2 (7), 491-496.

PAPAZACHOS, B.C. and P.E. CoMninakIs (1971): Geophysical and tectonic features of the Aegean Arc, $J$. Geophys. Res., 76, 8517-8533.

PLATT, J.P. and R.L.M. VISSERS (1989): Extensional collapse of overthickened continental lithosphere: a new working hypothesis for the Alboran Sea and Gibraltar arc, Geology, 17, 485-594.

RABINOWITZ, P.D. and W.B.F. RYAN (1970): Gravity anomalies and crustal shortening in the Eastern Mediterranean, Tectonophysics, 10, 585-608.

RÉHault, J.P., E. Moussat and A. FABbri (1987a): Structural evolution of the Tyrrhenian back-arc basin, Mar. Geol., 74 (1), 123-150.

Réhault, J.P., J. Mascle, A. Fabbri, E. Mousat and M. Thommeret (1987b): The Tyrrhenian Sea before
Leg 107, in Kastens, K.A., Mascle, J., Auroux, C. et al., 1987, Proc., Init. Repts. (Pt. A), ODP, 107, 9-36.

Robertson, A. and ODP Leg 160 Scientific Party (1996): Mud volcanism on the Mediterranean ridge: initial results of Ocean Drilling Program Leg 160, Geology, 24 (3), 239-242.

Robin, C., P. Colantoni, M. Gennesseaux and J.P. RéHAULT (1987): Vavilov seamount: a mildly alkaline Quaternary volcano in the Tyrrhenian basin, Mar. Geol., 78, 125-136.

Rosencrantz, E., M.I. Ross and J.G. Sclater (1988): Age and spreading history of the Cayman trough as determined from depth, heat flow and magnetic anomalies, J. Geophys. Res., 93, 2141-2157.

Ryan, W.B.F., K.A. KAstens and M.B. CitA (1982): Geological evidence concerning compressionnal tectonics in the Eastern Mediterranean, Tectonophysics, 86, 213-242.

SARTORI, R. (1990): The main results of ODP Leg 107 in the frame of Neogene to recent geology of perityrrhenian areas, in KASTENS, K.A., MASClE, J., et al., 1990, Proc. ODP, Sci. Results, 107, College Station, TX (Ocean Drilling Program), 715-730.

SAVELLI, C. (1988): Late Oligocene to recent episodes of magmatism in and around the Tyrrhenian Sea: implication for the processes of opening in a young interarc basin of intra-orogenic (Mediterranean) type, Tectonophysics, 146, 163-181.

SchütTe, K.G. (1978): Crustal structure of Southern Italy, in Alps Apennines Hellenides, edited by H. Closs, D. ROEDER and K. SCHMIDT, Stuttgart, 315-321.

SElLI, R. and A. FABBRI (1971): Tyrrhenian: a Pliocene deep-sea., Rend. Atti Accad. Naz. Lincei, 50 (5), 580-592.

Selli, R., F. Lucchini, P.L. Rossi, C. Savelli and M. DEL MonTe (1977): Dati geologici, petrochimici e radiomatrici sui volcani centrotirrenci, G. Geol., 2 (42), 221-246.

SPAKMAN, W., M.J.R. Wortel and N.J. VlaAR (1988): The Hellenic subduction zone: a tomographic image and its geodynamic implications, Geophys. Res. Lett. 15, 60-63.

Stride, A.H., R.H. Belderson and R.H. KenYON (1977): Evolving Miogeanticlines of the East Mediterranean (Hellenic, Calabrian and Cyprus outer ridges), Philos. Trans. R. Soc. London, 284, 255-285.

Truffert, C., N. Chamot-Rooke, S. Lallemant, B. De Voogd, P. Huchon and X. Le Pichon (1993): The crust of the Western Mediterranean ridge from deep seismic data and gravity modelling, Geophys. J. Int., 114, 360-372.

WoIDT, W.D. (1978): Finite element calculations applied to salt-dome analysis, Tectonophysics, 50, 369-386. 